PRACE NAUKOWE UNIWERSYTETU EKONOMICZNEGO WE WROCLAWIU

\title{
Pawel Kamiński
}

Uniwersytet Ekonomiczny we Wrocławiu

e-mail: pawel.ryszard.kaminski@gmail.com

\section{PROGRAM DOM KULTURY + INICJATYWY LOKALNE NARODOWEGO CENTRUM KULTURY JAKO INSTRUMENT WSPIERANIA BUDOWY LOKALNEGO KAPITALU SPOLECZNEGO}

\section{THE PROGRAM HOUSE OF CULTURE + LOCAL INITIATIVES OF THE NATIONAL CULTURAL CENTRE AS AN INSTRUMENT TO SUPPORT THE DEVELOPMENT OF LOCAL SOCIAL CAPITAL}

DOI: $10.15611 /$ pn.2017.477.09

JEL Classification: Z18

\begin{abstract}
Streszczenie: Celem artykułu jest próba odpowiedzi na pytanie, czy program Dom Kultury+ Inicjatywy lokalne Narodowego Centrum Kultury może być skutecznym narzędziem wspierania rozwoju lokalnego kapitału społecznego? Poszukiwaniu odpowiedzi na to pytanie posłużyło m.in. badanie sondażowe przeprowadzone na potrzeby niniejszego opracowania wśród beneficjentów programu - tj. dyrektorów i pracowników domów, ośrodków i centrów kultury biorących udział w programie.
\end{abstract}

Słowa kluczowe: kapitał społeczny, instytucja kultury.

Summary: This article attempts to answer the question about whether the program House of Culture + Local Initiatives of The National Center for Culture can be an effective tool to support the development of local social capital. The search for answers to this question helped Among others the survey conducted for this study among the beneficiaries of the program the directors and employees of homes, centers and cultural centers participating in the program helped to find the answer to the question.

Keywords: social capital, cultural institution.

\section{Wstęp}

Lokalne instytucje kultury, takie jak domy, ośrodki i centra kultury, stają się w coraz większym stopniu aktywnymi uczestnikami życia społecznego w środowiskach lokalnych. Zmiany te mają związek m.in. z promowaniem w ostatnich latach przez 
Narodowe Centrum Kultury modelu tzw. społecznościowego domu kultury. Upowszechnianiu tego modelu służy m.in. realizowany od 2013 r. program dotacyjny Dom Kultury+Inicjatywy lokalne.

Biorąc pod uwagę cele i sposób realizacji programu, a także intencje jego twórców, można postrzegać go jako instrument budowania lokalnego kapitału społecznego poprzez włączanie mieszkańców do udziału w kulturze.

\section{Kapitał społeczny}

Pojęcie kapitału społecznego jest terminem wieloznacznym, z pogranicza ekonomii i socjologii. Koncepcje kapitału społecznego pojawiły się m.in. jako odpowiedź na niedostatki klasycznych teorii ekonomicznych, które ignorowały lub umniejszały rolę ,miękkich” czynników w zrozumieniu przyczyn wzrostu gospodarczego. Obecnie kapitał społeczny uważa się za jeden z najważniejszych czynników rozwoju [Kuchmacz 2016, s. 71]. Umożliwia on zbiorowe działanie i osiąganie wspólnych celów, które przynoszą korzyści zbiorowości. Kapitał społeczny sprzyja kooperacji, innowacyjności i podnosi efektywność, zwiększając w ten sposób konkurencyjność [Sztompka 2016, s. 312-313].

Po raz pierwszy pojęcia kapitału społecznego użyła w 1916 r. Lynda H. Hanifan, nauczycielka z Charleston, socjolożka amatorka poszukująca sposobów mobilizacji lokalnej społeczności do wspólnych działań doskonalących poziom nauczania [Sztompka 2016, s. 286]. Odkryła ona, że tworzenie wokół szkoły zintegrowanej wspólnoty rodziców, regularne spotkania i organizacja wspólnych imprez wpływają na poprawę wyników szkolnych i ograniczają istnienie patologii. Kontakt jednostki z innymi członkami wspólnoty lokalnej pozwala zaspokoić potrzeby społeczne jednostki, a jednocześnie przyczynia się do poprawy warunków życia całej wspólnoty [Sztompka 2016, s. 287].

Upowszechnienie pojęcia kapitału społecznego można wiązać m.in. z nazwiskiem P. Bourdieu. Według niego zasób kapitału społecznego jednostki zależy od wielkości sieci, którą jest ona w stanie efektywnie mobilizować, oraz od zakresu kapitału symbolicznego i kulturowego posiadanego przez każdą osobę, z którą dana jednostka jest powiązana [Rymsza 2007, s. 24-25].

Kolejnym badaczem mającym istotny wkład w definiowanie kapitału społecznego jest J. Coleman. Stwierdził on, że kapitał społeczny jest ulokowany w strukturze relacji między działającymi jednostkami i nie mieści się w samych jednostkach ani w fizycznych narzędziach produkcji [Sztompka 2016, s. 290]. Jego zdaniem kapitał społeczny zwiększa skuteczność działania grupy. Coleman do swoich odkryć doszedł, badając żydowskich dilerów diamentów w Nowym Jorku, którzy wielomilionowe transakcje zawierają ustnie, bez podpisywania kontraktów i bez udziału notariuszy. Dzięki zaufaniu i przestrzeganiu wewnątrzgrupowych norm społeczność ta oszczędza na kosztach transakcyjnych i zyskuje przewagę rynkową [Sztompka2016, s. 289]. 
Czynnik zaufania bardzo silnie pojawił się również w pracach R.D. Putnama, który przez blisko 20 lat badał instytucje publiczne we Włoszech. Według niego zaufanie jest zasadniczym składnikiem kapitału społecznego [Putnam 1995, s. 264]. Dzięki zaufaniu ludzie rezygnują z izolacji, łączą swoje wysiłki i podejmują „grę zespołową". Kapitał społeczny jest według niego dobrem publicznym. Z taką definicją wiąże się pojęcie uogólnionej wzajemności. Mamy z nim do czynienia wówczas, „gdy zachodzi ciągła wymiana dóbr, która w danym momencie nie w pełni odbywa się na zasadzie rewanżu - a więc jest niezrównoważona - ale opiera się na wzajemnym przeświadczeniu, że wyświadczone teraz usługi będą wynagrodzone w przyszłości” [Putnam 1995, s. 267].

Koncepcję kapitału społecznego rozwinął również F. Fukuyama. W jego ujęciu kapitał społeczny to zdolność wynikająca z rozpowszechnienia zaufania w obrębie społeczeństwa lub jego części, podstawa zaufania i zdrowej gospodarki [Fukuyama 1997, s. 39]. Gromadzenie kapitału społecznego wymaga zaakceptowania norm moralnych danej społeczności. Jeżeli pomiędzy współpracownikami istnieje wzajemne zaufanie, prowadzenie interesów jest mniej kosztowne. Fukuyama wskazuje substytut zaufania, którym jest ,aparat mechanizmów legislacyjnych”. Jego funkcjonowanie pociąga za sobą tzw. koszty transakcyjne [Fukuyama 1997].

Kapitał społeczny ma istotne znaczenie dla rozwoju lokalnego. Według Ryszarda Brola kapitał społeczny można utożsamiać z trwałością porządku społecznego w organizacji, grupie społecznej, społeczności lokalnej - rozumianą jako zasób trwałych społecznych wartości, uruchamiający strumień korzyści ekonomicznych osiąganych przez organizacje, społeczności, grupy społeczne, a nieosiągalnych dla innych społeczności tworzących mniej trwały porządek społeczny [Brol 2008, s. 317].

Zaznaczyć należy, że zbyt silne sieci kapitału społecznego mogą nieść za sobą również negatywne skutki. Należą do nich takie zjawiska, jak: wykluczanie, ograniczanie możliwości działania, ograniczanie indywidualnej swobody działania oraz zaniżanie ambicji i standardów społecznych. Skrajną formą tzw. negatywnego kapitału społecznego są struktury mafijne [Sztompka 2016, 329].

\section{Rola lokalnych instytucji kultury w budowaniu lokalnego kapitału społecznego}

Niniejsze opracowanie dotyczy lokalnych instytucji kultury, takich jak: domy, ośrodki i centra kultury. Mają one status instytucji kultury w myśl Ustawy o organizowaniu i prowadzeniu działalności kulturalnej, tj. podmiotów, których podstawowym celem jest prowadzenie działalności kulturalnej [Ustawa z 25 października 1991]¹. Domy, ośrodki i centra kultury, to druga po bibliotekach grupa instytucji kultury w Polsce pod względem liczebności. Według raportu Głównego Urzędu Statystycz-

${ }^{1}$ Dalej jako Ustawa o organizowaniu i prowadzeniu działalności kulturalnej. 
nego w 2015 r. domów i ośrodków kultury było w Polsce 2441 [Łysoń (red.) 2016, s. 78-79].

Rolę lokalnych instytucji kultury jako podmiotów budujących lokalny kapitał społeczny postulowali m.in. Barbara Jedlewska i Bogdan Skrzypczak. Według nich kapitał społeczny winien być jednym z najmocniejszych filarów nowoczesnych domów kultury [Jedlewska, Skrzypczak (red.) 2009, s. 15]. Podobny pogląd prezentuje również Marek Krajewski. W swojej koncepcji uczestnictwa w kulturze zwraca uwagę na „zagęszczanie relacji społecznych”, śledzenie powiązań pomiędzy poszczególnymi elementami (tego jak są tworzone, podtrzymywane i wzmacniane lub zrywane) [Krajewski 2013, s. 29]. Koncepcje te stały się teoretyczną podwaliną stworzenia przez Narodowe Centrum Kultury m.in. takich programów, jak Dom Kultury+ Inicjatywy lokalne czy Bardzo Młoda Kultura.

Lokalne instytucje kultury znalazły się również w grupie podmiotów istotnych dla realizacji Strategii Rozwoju Kapitału Społecznego 2020, przyjętej Uchwałą Rady Ministrów z dnia 26 marca 2013 r. [Uchwała nr 61 Rady Ministrów] Strategia przewiduje m.in., że jednym z istotnych zadań będzie rozwój ośrodków kultury jako lokalnych centrów kultury oraz wspieranie ich rozwoju jako ośrodków aktywności kulturalnej i obywatelskiej. Lokalne instytucje kultury mają być również podmiotami wspierającymi mechanizmy współpracy instytucji publicznych z obywatelami jako naturalna przestrzeń, w której mogą realizować działania na rzecz dobra wspólnego.

\section{Program Dom Kultury+ Inicjatywy lokalne jako instrument budowania lokalnego kapitału społecznego}

Program Dom Kultury+ Inicjatywy lokalne jest jednym z programów dotacyjnych Narodowego Centrum Kultury. Często bywa nazywany „kulturalnym budżetem obywatelskim". Celem strategicznym programu jest inicjowanie działań służących wzmocnieniu zaangażowania domów kultury w życie społeczności lokalnej, odkrywaniu i rozwijaniu potencjału i kapitału kulturowego jej członków oraz kulturotwórczych zasobów społeczności.

Działania podejmowane przy realizacji zadań w ramach realizacji programu mają służyć przede wszystkim: inicjowaniu nowych praktyk w zarządzaniu instytucją kultury, odkrywaniu i pobudzaniu aktywności społecznej, wspomaganiu rozwoju kapitału społecznego i kulturowego, a także poznawaniu nowych możliwości współpracy z mieszkańcami.

W programie Dom Kultury+ Inicjatywy lokalne główny nacisk programu położony jest na nawiązywanie przez dom kultury stałych relacji z mieszkańcami miejscowości, na których terenie działa. Odkrywanie talentów i wzmacnianie potencjału społecznego ma owocować stworzeniem wspólnych inicjatyw na rzecz społeczności lokalnych i przestrzeni publicznej [Regulamin Programu Narodowego Centrum Kultury]. Program jest realizowany od 2013 r. W każdej edycji bierze w nim udział 
50 domów kultury wyłanianych w drodze konkursu. Oznacza to, że obecnie uczestniczy w programie 250 instytucji, co stanowi zaledwie 10,2\% domów kultury w Polsce.

Na potrzeby programu zdefiniowany został model domu kultury. Zgodnie z założeniami Narodowego Centrum Kultury modelowy dom kultury powinien:

- posiadać umiejętność budowy strategii rozwoju i funkcjonowania w oparciu o analizę lokalnej sytuacji społeczno-ekonomicznej;

- być aktywnym uczestnikiem życia społecznego w danej gminie;

- stwarzać możliwości wielostronnej edukacji kulturalnej;

- być otwartym na wszystkie grupy społeczne;

- kształcić postawy aktywnego uczestnictwa w kulturze;

- angażować artystów w życie kulturalne społeczności lokalnych;

- integrować społeczności lokalne za pomocą działań kulturalnych;

- przeciwdziałać wykluczeniu społecznemu i jego skutkom;

- przyczyniać się do rozwoju gminy;

- być moderatorem dialogu w społeczności lokalnej;

- budować postawy otwartości i tolerancji².

W ramach programu lokalne instytucje kultury mogą ubiegać się o dofinansowanie realizacji zadania składającego się z dwóch części. Maksymalne kwoty dofinansowania wynoszą 8000 zł dla pierwszej części zadania i 22000 zł dla drugiej części. Pierwsza część zadania obejmuje:

- przeprowadzenie diagnozy identyfikującej zasoby i samodzielne inicjatywy mieszkańców w danej społeczności lokalnej;

- opracowanie i udostępnienie do wiadomości publicznej zasad wyboru inicjatyw, zgodnie z zasadą przejrzystości i równego traktowania podmiotów je zgłaszających;

- w oparciu o zasady, o których mowa w pkt 2, dokonanie wyboru od 3 do 7 różnorodnych inicjatyw wraz z uzasadnieniem wyboru podanym do publicznej wiadomości;

- z uwzględnieniem zasobów infrastrukturalnych i kadrowych instytucji stworzenie wraz z autorami wybranych inicjatyw planu ich wspólnej realizacji, obejmującego opisy, harmonogram działań, preliminarz wydatków, wskaźniki rezultatu. Druga część zadania obejmuje: realizację wspólnie z autorami wybranych inicjatyw oraz dokonanie ewaluacji zadania uwzględniającej wszystkie przeprowadzone w ramach zadania inicjatywy [Regulamin Programu Narodowego Centrum Kultury]. W realizacji programu beneficjentów wspomagają wskazani przez Narodowe Centrum Kultury animatorzy. Istnieje tu pewna analogia z tworzeniem lokalnych partnerstw trójsektorowych, gdzie animator pełni rolę koordynatora i „katalizatora” budowania kapitału społecznego w partnerstwie [Kuchmacz 2016, s. 109].

${ }^{2}$ Strona internetowa Narodowego Centrum Kultury, http://nck.pl/dom-kultury/ (31.08.2016). 


\section{Skuteczność programu Dom Kultury+ Inicjatywy lokalne w budowaniu lokalnego kapitału społecznego w świetle badań sondażowych}

Narodowe Centrum Kultury poddało ewaluacji realizację programu w roku 2013. Badanie to nie miało na celu oceny efektów w kontekście budowania lokalnego kapitału społecznego. Jednak niektóre wyniki pośrednio potwierdzają skuteczność programu w tym zakresie. W badaniu korzyści odniesionych przez mieszkańców $\mathrm{z}$ udziału w inicjatywach, przeprowadzonym wśród odbiorców inicjatyw realizowanych w ramach programu w 2013 r., blisko 69,4\% wskazało możliwość podtrzymania już istniejących więzi z innymi mieszkańcami. Niewiele mniejsza grupa respondentów - 68,5\% - wskazała jako korzyść bliższe poznanie nowych osób. Dość mocno podkreślano również obywatelsko-emancypacyjny wątek związany z uczestniczeniem w projekcie. Uczestnicy badania wskazywali, że wciągnięcie mieszkańców do realizowania inicjatyw, uczynienie ich nie tylko pomysłodawcami, ale również osobami odpowiedzialnymi za terminową i zgodną z budżetem realizację miało niezwykle pozytywne skutki. Nie tylko przekonano odbiorców, że warto aktywnie starać się o realizację swoich marzeń, ale również ugruntowano ich poczucie wpływu na otaczającą rzeczywistość. W swoich wypowiedziach badani zwracali uwagę, że program uczył umiejętności niezbędnych do zgłaszania i realizacji projektów związanych z budżetem obywatelskim [Raport 2014, s. 151-152].

Skuteczność programu jako instrumentu wspierania rozwoju lokalnego kapitału społecznego dostrzegają również pracownicy instytucji uczestniczących w programie. Potwierdzają to wyniki badania ankietowego przeprowadzonego wśród uczestników spotkania beneficjentów programu, które odbyło się w Chorzowskim Centrum Kultury w dniach 28-29 kwietnia 2016 r. W badaniu wzięło udział 50 osób, w tym 28 dyrektorów oraz 22 pracowników merytorycznych. Połowa respondentów pochodziła z gmin wiejskich, $14 \% \mathrm{z}$ miejsko-wiejskich, a $36 \% \mathrm{z}$ miejskich. W badaniu wzięło udział 30 kobiet i 20 mężczyzn. Pytania skierowane do badanych dotyczyły różnych elementów składowych kapitału społecznego, takich jak: więzi, aktywność, współpraca, wpływ oraz zaufanie. Badanie inspirowane było metodologią opracowaną w ramach projektu „BOX - Badanie Oddziaływania na Kapitał Społeczny" Polsko-Amerykańskiej Fundacji Wolności oraz Fundacji Pracownia Badań i Innowacji Społecznych Stocznia ${ }^{3}$.

Na pytania dotyczące więzi - „Czy w Twojej opinii, w wyniku realizacji programu Dom Kultury+ Inicjatywy lokalne siła przywiązania poszczególnych członków do społeczności zmieniła się?" - $62 \%$ badanych zauważyło wzrost, w tym $8 \%$ zdecydowany. Tylko 1 osoba zaobserwowała spadek, a 36\% nie zauważyło żadnej zmiany. Podobnych odpowiedzi badani udzielili na pytanie o poczucie przynależności do wspólnoty mieszkańców objętych działaniami. Również $62 \%$ badanych zauważyło

${ }^{3}$ BOX - Badanie Oddziaływania na Kapitał Społeczny, www.kapitalspoleczny.org (21.04.2016). 
wzrost, w tym $10 \%$ istotny wzrost. $38 \%$ nie zauważyło zmiany. Podobny rozkład mają odpowiedzi na pytanie o przywiązanie mieszkańców do norm ułatwiających wspólne działanie.

Uczestnicy ankiety nie mieli dużych wątpliwości co do oceny wpływu programu na aktywność mieszkańców zaangażowanych w realizowane inicjatywy. Na pytanie o zdolność do podejmowania działań w ramach społeczności aż 86\% respondentów zauważyło wzrost, w tym $20 \%$ zdecydowany.

Mniej jednoznaczne odpowiedzi padły na pytania dotyczące współpracy. Na pytanie o zmianę zdolności uzgadniania swoich działań i unikania konfliktów jedynie $4,1 \%$ respondentów zauważyło zdecydowany wzrost. Wzrost umiarkowany zaobserwowało 53,1\% respondentów. Brak zmiany $36,7 \%$, a spadek $6,1 \%$ badanych.

Podzielone opinie dotyczyły również zmiany zdolności członków społeczności do wywierania wpływu na zbiorowe decyzje. 14\% badanych zaobserwowało jej spadek. Brak zmian zadeklarowało 36\% respondentów. W opinii połowy badanych zdolność ta wzrosła, w tym zdaniem 10\% w sposób zdecydowany.

Bardziej zdecydowane wskazania dotyczyły innego kluczowego składnika kapitału społecznego, jakim jest zaufanie. W opinii $74 \%$ badanych w wyniku realizacji programu wiara w przewidywalność zachowań poszczególnych członków społeczności i ich dobre intencje wzrosła, w tym zdaniem $18 \%$ badanych wzrost ten był zdecydowany, $12 \%$ badanych nie zaobserwowało zmiany, a 2\% stwierdziło spadek zaufania.

Biorąc pod uwagę dość jednoznaczne wyniki przeprowadzonej ankiety, można przyjąć, że w opinii dyrektorów i pracowników lokalnych instytucji kultury Program Dom Kultury+ Inicjatywy lokalne jest skutecznym narzędziem wspierania budowania lokalnego kapitału społecznego. Uczestnicy badania zaobserwowali bowiem wzrost praktycznie wszystkich wskazanych w badaniu elementów składowych kapitału społecznego.

Należy zaznaczyć, że opisane badanie nie wyczerpuje tematu roli instytucji kultury we wspieraniu budowania lokalnego kapitału społecznego. Zaprezentowane opinie beneficjentów programu Dom Kultury+ Inicjatywy lokalne należy potraktować jako przyczynek i punkt wyjścia do badań na ten temat.

\section{Zakończenie}

Instytucje-beneficjenci programu Dom Kultury+ Inicjatywy lokalne stanowią nieliczną grupę wśród wszystkich funkcjonujących w kraju domów, ośrodków i centrów kultury. Można zaryzykować tezę, że równie nieliczną grupę stanowią instytucje w sposób świadomy uczestniczące w budowaniu lokalnego kapitału społecznego. Jednak efekty ewaluacji programu, jak i wyniki badania sondażowego przeprowadzonego wśród beneficjentów wskazują, że program może być efektywnym narzędziem wspierania procesu budowania kapitału społecznego przez lokalne instytucje 
kultury. Biorąc pod uwage jego ograniczoną skalę - 50 instytucji rocznie od 2013 roku - zasadne wydaje się poszerzenie liczby instytucji biorących udział w programie.

Zaznaczyć należy, że program Dom Kultury+Inicjatywy lokalne nie jest jedynym dostępnym instrumentem wspierania procesu budowania kapitału społecznego przez lokalne instytucje kultury. Wzrost poczucia przynależności, zdolności do współpracy, aktywność czy wreszcie poziomu zaufania w relacjach pomiędzy instytucją a mieszkańcami można osiągnąć, nie uczestnicząc w programie, wykorzystując inne narzędzia włączające mieszkańców, takie jak np. budowanie oferty instytucji z udziałem społeczności czy lokalne mikrogranty na inicjatywy kulturalne.

\section{Literatura}

Brol R., 2008, Kapitat społeczny w gospodarce lokalnej, [w:] Brol R. (red.), Gospodarka lokalna i regionalna $w$ teorii i praktyce, Prace Naukowe Uniwersytetu Ekonomicznego we Wrocławiu, nr 3(1203).

Fukuyama F., 1997, Zaufanie. Kapitat spoteczny a droga do dobrobytu, Wydawnictwo Naukowe PWN, Warszawa.

Jedlewska B., Skrzypczak B. (red.), 2009, Dom kultury w XXI wieku. Wizje, niepokoje, rozwiazania, Centrum Edukacji i Inicjatyw Kulturalnych, Olsztyn.

Krajewski M., 2013, W kierunku relacyjnej koncepcji uczestnictwa w kulturze, Kultura i Społeczeństwo, nr 1.

Kuchmacz B., 2016, Kapitat społeczny jako czynnik rozwoju lokalnego, CeDeWu Sp. z o.o., Warszawa. Łysoń P. (red.), 2016, Kultura 2015. Informacje i opracowania statystyczne, Główny Urząd Statystyczny, Warszawa.

Putnam R.D., 1995, Demokracja w działaniu. Tradycje obywatelskie we współczesnych Włoszech, Wydawnictwo Znak, Kraków.

Rymsza A., 2007, Klasyczne koncepcje kapitału społecznego, [w:] Kaźmierczak T., Rymsza M. (red.), Kapitat społeczny. Ekonomia społeczna, Wydawnictwo Fundacja Instytutu Spraw Publicznych, Warszawa.

Sztompka P., 2016, Kapitat społeczny. Teoria przestrzeni międzyludzkiej, Wydawnictwo Znak, Kraków. Raport, 2014, Raport końcowy. Badanie ewaluacyjne pn. Opracowanie metodologii oraz przeprowadzenie badań ewaluacyjnych II I III edycji Programu Dom Kultury+: Dom Kultury+, Edukacja Artystyczna (2012) oraz Dom Kultury+ Inicjatywy lokalne (2013), Public Profits sp. z o.o., Poznań.

Regulamin Programu Narodowego Centrum Kultury Dom Kultury+ Inicjatywy lokalne 2016, http:// nck.pl/media/attachments/317303/regulamin_DK_2016.pdf (31.08.2016).

Uchwała nr 61 Rady Ministrów z dnia 26 marca 2013 r. w sprawie przyjęcia „Strategii Rozwoju Kapitału Społecznego 2020", M.P. z dnia 16 maja 2013 r., poz. 378.

Ustawa z dnia 25 października 1991 r. o organizowaniu i prowadzeniu działalności kulturalnej, Dz.U. z 2012 r., poz. 406. 